\title{
PENGGUNAAN DOKSISIKLIN HYCLATE SEBAGAI INHIBITOR MATRIKS METALLOPROTEINASE PADA TERAPI TAMBAHAN PERIODONTITIS
}

\author{
Risma Aprinda Kristanti \\ Jurusan Biologi, Fakultas Sains dan Teknologi UIN Maliki Malang \\ E-mail: risma_kristanti@yahoo.com
}

\begin{abstract}
Terbit.com Daily has reported that the prevalence of periodontitis increases related with age person. Found that $35,7 \%$ of patients with periodontitis in the group 30-39 years old to 66,5\% in the group 50-59 years old, increase $89,2 \%$ in the group $80-90$ years old. Periodontitis that commonly found is a chronic periodontitis which is occurs in individuals older than 45 years, but can also be found in children.

The main characteristic of periodontitis is the damage of the periodontal connective tissue, alveolar bone, and the movement of the junctional epithelium to the apical. Bacterial components may directly or indirectly cause tissue damage. Inflammatory mediators product such as proteinases, cytokines, and prostaglandins are part of the host response that can also cause tissue damage. Matrix metalloproteinase (MMP) is a proteinase that can cause periodontal tissue damage by disrupting the extracellular matrix molecules in periodontal tissues.

Since is known that MMP has a role in various pathological processes, therapy to inhibit activity MMP in pathological processes has developed. MMP inhibitors will be a useful adjunct therapy for the treatment of periodontal disease. Many products have been introduced as an MMP inhibitor, for example: tetracycline and various derivatives, such as doxycycline and minocycline which are capable of inhibiting the activity of several classes of MMPs. Doxycycline has the ability to inhibit the increase in collagenase activity that is pathological in subgingival and prevent periodontitis to become more severe.
\end{abstract}

Keywords: doxyxycline, matriks metalloproteinase, periodontitis

\section{A. PEndahuluan}

Harian Terbit.Com melaporkan bahwa periodontitis mempunyai prevalensi yang meningkat dengan bertambahnya usia seseorang. Ditemukan $\quad 35,7 \% \quad$ penderita periodontitis pada kelompok usia 3039 tahun menjadi $66,5 \%$ pada kelompok usia 50-59 tahun. Bahkan $89,2 \%$ pada kelompok usia $80-90$ tahun. Periodontitis yang banyak ditemukan adalah periodontitis kronis yang umum terjadi pada individu berusia lebih dari 45 tahun, tetapi dapat juga ditemukan pada anak-anak (Harian Terbit.Com, 2005).

Ciri utama dari periodontitis adalah kerusakan pada jaringan ikat periodontal, tulang alveolar, dan penurunan junctional epithelium. Komponen bakteri dapat secara langsung maupun tidak langsung menyebabkan kerusakan jaringan. Mediator inflamasi yang diproduksi seperti proteinase, sitokin, dan prostaglandin merupakan bagian dari respon host yang juga dapat menyebabkan terjadinya kerusakan jaringan. Matriks Metalloproteinase (MMP) merupakan proteinase 
yang dapat menyebabkan kerusakan jaringan periodontal dengan cara merusak molekul matriks ekstraseluler pada jaringan periodontal. (Carranza et al, 2002).

Sejak diketahui bahwa MMP memiliki peran dalam berbagai proses patologik, maka usaha mengatasi keterlibatan MMP dalam proses patologik ditujukan pada pengembangan inhibitor untuk melawan aktivitas MMP. (Preshaw et al, 2004)

Inhibitor MMP akan menjadi terapi tambahan yang berguna bagi perawatan penyakit periodontal. Banyak produk yang telah diperkenalkan sebagai inhibitor MMP, contohnya adalah tetrasiklin dan berbagai derivatnya, misalnya doksisiklin dan minosiklin yang mampu menghambat aktivitas beberapa golongan MMP. Doksisiklin memiliki kemampuan menghambat peningkatan aktivitas kolagenase yang bersifat patologik dalam subgingiva dan mencegah perkembangan periodontitis. (Gendron et al, 1999)

Kata kunci: doksisiklin, matriks metalloproteinase, periodontitis

\section{Jaringan Periodontal}

Jaringan periodontal pada rongga mulut manusia meliputi: gingiva, ligamen periodontal, tulang alveolar, dan sementum. Secara klinis bagian peridontal yang terlihat hanya gingiva yang membalut tulang alveolar dan mengelilingi gigi. Ligamen periodontal, tulang alveolar, dan sementum merupakan suatu unit fungsional yang mendukung gigi pada soketnya. Sebagai suatu unit fungsional, ketiga jaringan tersebut secara bersamasama sering dinamakan sebagai struktur periodontal pendukung. (Daliemunthe, 1995)

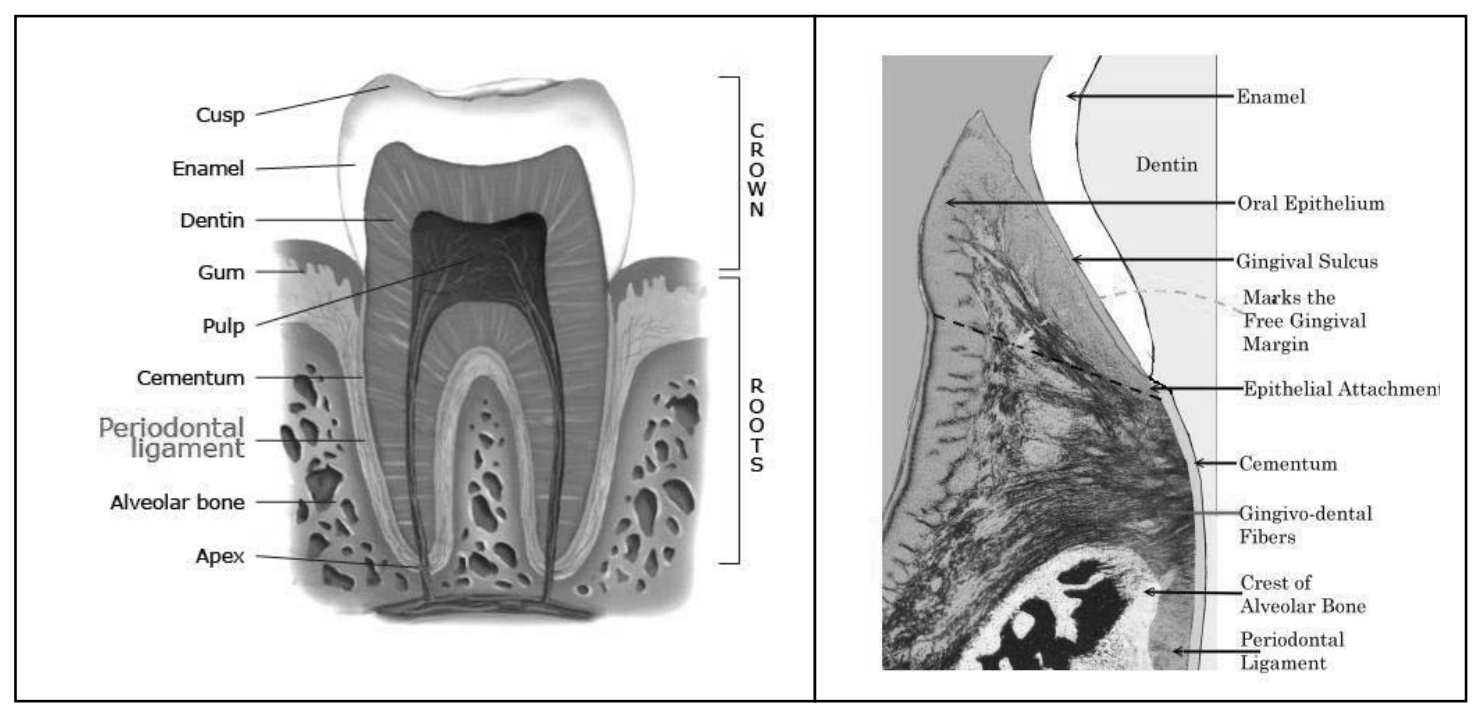

Gambar 1. Jaringan Periodontal

2. Matriks Ekstraseluler dan Matriks (MMP) pada Jaringan Periodontal

Matriks ekstraseluler pada ligamen periodontal terdiri dari dua komponen utama, yaitu serat dan substansi dasar. Komponen serat berperan dalam hal menjaga daya regang jaringan, sedangkan substansi dasar berfungsi untuk menahan kekuatan kompresi. (Berkovitz et al, 1995). Pada jaringan periodontal, dapat ditemukan kolagen bentuk 
fibril tipe I, III, IV, V, VI, dan XII, yang terbanyak adalah Kolagen tipe I, terdapat di ligamen periodontal sekitar $80 \%$, sedangkan kolagen tipe III yang berfungsi untuk kematangan jaringan ikat, jumlahnya kurang lebih $20 \%$ dari jumlah total kolagen (Bartold \& Narayanan, 1998; Berkovitz et al, 1995).

Kolagen merupakan protein serat terbanyak yang ditemukan pada jaringan ikat. Selain itu pada jaringan ikat juga dapat ditemukan protein serat yang lain, yaitu serat elastik. Serat elastik terdiri dari tiga tipe, yaitu: serat elastin, elauin, dan oxytalin. (Berkovitz et al, 1995).

MMP atau disebut juga matrixins adalah golongan enzim proteolitik berasal dari sel host yang memiliki peran penting pada kerusakan jaringan akibat keradangan, seperti periodontitis. (Nagase et al, 1997; Gendron et al, 1999). MMP merupakan suatu polipeptida dengan ukuran bervariasi antara 20 sampai $100 \mathrm{kDa}$. (Pirila, 2003). MMP merupakan proteinase yang dapat menyebabkan kerusakan jaringan periodontal dengan cara merusak molekul matriks ekstraseluler pada jaringan periodontal. (Carranza et al, 2002).

MMP terdiri dari sebuah sinyal peptida, sebuah domain propeptida, domain katalitik, dan domain ujung $\mathrm{COOH}$. Sinyal peptida mengandung sebuah urutan asam amino transmembran yang mengikat enzim ini pada membran. Domain propeptida dimulai dari ujung $\mathrm{N}$ sampai domain katalitik. Domain ini mengandung deret urutan asam amino PRCGVPD atau disebut juga deret cysteine switch, berfungsi untuk mempertahankan enzim dalam bentuk inaktif. Domain katalitik mengandung dua ion $\mathrm{Zn}^{2+}$, salah satunya berfungsi struktural, selain itu juga terdapat satu sampai tiga ion $\mathrm{Ca}^{2+}$ (tergantung dari jenis MMP) yang terikat pada domain ini, $\mathrm{Ca}^{2+}$ diperlukan oleh MMP untuk dapat berfungsi. Pada domain katalitik terdapat urutan asam amino $\mathrm{HE} X \mathrm{GH} X X X X X \mathrm{HS}$ dengan tiga residu Histidin dan residu Glutamat yang merupakan tempat pengikatan $\mathrm{Zn}^{2+}$. Domain katalitik menentukan cleavage site secara spesifik melalui celah active site dan terhubung dengan ujung karboksi (C) pada domain hemopexin oleh peptida penghubung yang kaya protein. (Pirila, 2003). Ujung karboksi (C) pada domain hemopexin berbentuk cakram ellipsoidal dengan empat bilah struktur- $\beta$ seperti baling-baling, setiap bilah mengandung empat $\beta$ strands antiparalel dan sebuah $\alpha$ helix. (Nagase et al, 1999). Ciri khas celah active site MMP adalah memotong sampai permukaan domain ellipsoidal. Pada left-hand site relative rendah dan mengandung $\mathrm{Zn}^{2+}$ katalitik pada pusatnya, tetapi lebih dalam pada right-hand site. Domain katalitik berfungsi untuk hidrolisis enzim dan interaksi dengan inhibitor. (Murphy et al, 2002).

Semua jenis MMP ditranslasi dengan sebuah deret hidrofobik ujung $\mathrm{NH}_{2}$ yang mengatur perjalanan enzim melalui retikulum endoplasma dan golgi apparatus, dan selanjutnya disekresi menuju ruangan ekstraseluler. Selama proses translasi, rantai lengkap MMP berada dalam bentuk prepro. Predomain amino pada bagian ujung amino $(\mathrm{N})$ dari preMMP mengandung bagian deret hidrofobik yang mengarahkan enzim ini menuju jalur sekretoris. Deret sinyal peptida tidak dipecah sehingga akan menghasilkan proMMP yang inaktif. Pada proses 
aktivasi MMP, prodomain dilepas atau enzim mengalami perubahan konformasi menjadi proteinase yang aktif. (Murphy et al, 2002). MMP akan aktif pada keadaan $\mathrm{pH}$ netral (Khoswanto \& Arijani, 2004).

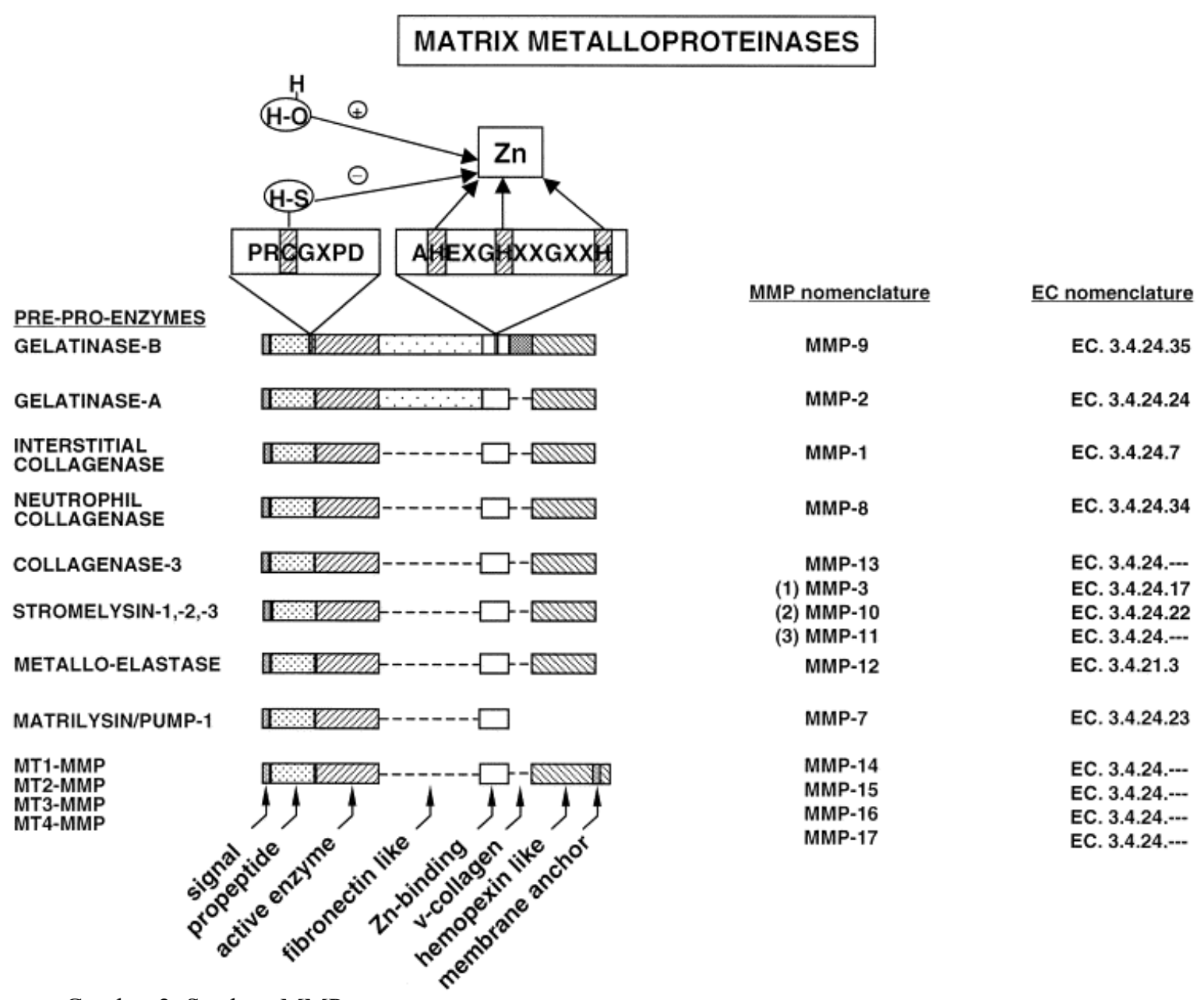

Gambar 2. Struktur MMP

\section{Periodontitis}

Penyakit periodontal adalah penyakit yang menyerang jaringan penyangga gigi, secara garis besar dibagi menjadi dua kelompok, yaitu gingivitis dan periodontitis. Gingivitis adalah keradangan yang menyerang gingiva, sedangkan periodontitis adalah keradangan yang menyerang jaringan periodontal yang lebih dalam. Penyebab utama penyakit periodontal adalah akumulasi plak bakteri. Selain akumulasi plak bakteri, ada faktor pendukung lainnya, yaitu karies, perawatan orthodontia, pemakaian gigi tiruan yang desainnya tidak tepat, merokok, susunan gigi yang tidak teratur, dan faktor daya tahan tubuh. (Academy of General Dentistry, 2002).

\section{Patogenesis}

\section{Periodontitis}

Penyakit

Terdapat beberapa keadaan yang dapat merusak struktur jaringan dan fungsi jaringan periodontal. Sebagai contohnya adalah keradangan, baik akut maupun kronik pada jaringan ikat gingiva yang dapat menyebabkan kerusakan matriks sehingga mengakibatkan kerusakan tidak hanya pada jaringan ikat 
gingiva tetapi juga pada ligamen periodontal dan tulang alveolar. Banyak penyakit sistemik dan obatobatan yang juga berperngaruh terhadap jaringan periodontal. (Bartold \& Narayanan, 1998).

Pada umumnya, proses yang menyebabkan terjadinya penyakit periodontal adalah sebagai berikut (American Academy of Periodontology, 2002; Carranza et al,2002) :

a. Bertambahnya bakteri dalam jumlah besar yang melekat pada permukaan gigi sampai membentuk lapisan tipis yang dikenal dengan plak.

b. Plak adalah deposit lunak yang membentuk lapisan biofilm, melekat pada permukaan gigi dalam rongga mulut.

c. Apabila plak tetap dibiarkan berada pada rongga mulut maka akan mengalami kalsifikasi menjadi kalkulus.

d. Kalkulus mempunyai konsistensi dan perlekatan yang kuat pada permukaan gigi. Warna dan kekerasannya tergantung dari umur material dan faktor ekstrinsik, seperti pemakaian tembakau. Walaupun bakteri plak berperan pada keradangan penyakit periodontal, tetapi kalkulus juga menyebabkan suatu peningkatan akumulasi plak pada permukaan gigi.

Iritasi plak bakteri dan keradangan yang terus menerus akan merusak integritas junctional epithelium. Sel-sel epitel akan mengalami degenerasi dan perlekatannya pada permukaan gigi mengalami kerusakan. Selanjutnya perlekatan epitel bergerak ke apikal dan membentuk poket periodontal, keadaan ini yang disebut periodontitis. (Eley \& Cox 1998).

\section{Matriks Ekstraseluler dan MMP Pada Periodontitis}

Tanda terjadinya keradangan pada jaringan periodontal adalah kerusakan jaringan ikat gingiva. Kerusakan pada jaringan ikat gingiva diawali dengan kerusakan pada matriks ekstraseluler dan sebagian besar kolagen pada pusat inflamasi. (Bartold \& Narayanan, 1998).

Terjadi proses fagositosis dan digestion oleh lisosomal secara intraseluler pada proses turnover kolagen yang normal, proses ini berjalan abnormal pada penyakit periodontitis (Berkovitz et al, 1995). Pada periodontitis terjadi kerusakan kolagen dan matriks ekstraseluler, adanya kerusakan kolagen menunjukkan bahwa penyebab periodontitis berhubungan dengan meningkatnya sintesis kolagenase oleh host sehingga menyebabkan meningkatnya degradasi kolagen. Kolagenase disintesis dan mula-mula dibebaskan dari neutrofil sebagai respon terhadap adanya infeksi oleh bakteri, yang selanjutnya menyebabkan terjadinya kerusakan kolagen. Kadar kolagenase bervariasi tergantung tingkat keparahan penyakit. Kadar kolagenase lebih tinggi pada cairan krevikular gingiva penderita periodontitis dibandingkan dengan cairan krevikular gingiva normal. (Berkovitz et al, 1995; Weinberg, 2004).

Yang memiliki peran penting dalam menimbulkan gejala klinik dan gambaran biokimia pada periodntitis adalah substansi bakteri dan mediator kimia yang dibebaskan oleh sel host. Diantara faktor-faktor yang ada, beberapa elemen memiliki peran aktif dalam proses perusakan tulang dan pembentukan poket. Pembebasan IL-1 $\beta$ oleh makrofag dan fibroblas serta sejumlah 
Prostaglandin $\mathrm{E}_{2} \quad\left(\mathrm{PGE}_{2}\right)$ sebagai hasil proses keradangan mampu merangsang osteoklas untuk meresorpsi tulang alveolar. Adanya kerusakan tulang alveolar menunjukkan peningkatan jumlah enzim protease terutama MMP. Dengan meningkatnya jumlah MMP, juga dapat menyebabkan kerusakan pada komponen kolagen ligamen periodontal dan gingiva (Bartold \& Narayanan, 1998).

Pada keadaan normal, regulasi MMP terjadi pada saat ekspresi gen dan kemudian disekresi menuju ekstraseluler. Gangguan pada regulasi MMP akan menyebabkan kerusakan jaringan ikat. (Weinberg, 2004). Infeksi bakteri yang kronik dapat menyebabkan keradangan kronik sehingga produksi sitokin meningkat dan terjadi induksi MMP oleh sel-sel host. (Berkovitz et al, 1995). Pada daerah yang mengalami infeksi, kerusakan kolagen lebih besar daripada regenerasi yang terjadi. (Perno, 2001).

Pada gingivitis, kerusakan matriks disebabkan aktivitas MMP yang dihasilkan oleh leukosit PMN (Bartold \& Narayanan, 1998). Pada jaringan periodontal, banyak sel yang dapat memproduksi MMP, antara lain : fibroblas, sel-sel epitel (keratinosit), sel-sel endotel, dan selsel inflamasi selama proses inflamasi berjalan. Jenis sel-sel yang berbeda tersebut memproduksi jenis MMP yang berbeda pula. Fibroblas memproduksi MMP-1 (Kolagenase1), tetapi tidak memproduksi MMP-8 (Kolagenase-2) dan MMP-9 (Gelatinase). Sebaliknya leukosit PMN mensekresi MMP-8 dan MMP9. (Bartold \& Narayanan, 1998).

Walaupun produksi kolagenase dari neutrofil merupakan bagian yang alami dari respon host terhadap infeksi pada penyakit periodontal dan keadaan keradangan yang lain, namun pada periodontitis terdapat ketidakseimbangan antara jumlah MMP yang merusak jaringan dan inhibitornya. (Weinberg, 2004). Jenis MMP terbanyak yang terdapat dalam cairan krevikular gingiva pada penderita periodontitis adalah MMP8 dan MMP-9. Kedua jenis MMP tersebut diproduksi oleh leukosit PMN dan yang paling sering menyebabkan kerusakan. (Preshaw at al, 2004).

Walaupun jenis MMP yang berbeda diproduksi oleh jenis sel-sel periodontal yang berbeda, dan setiap jenis sel memiliki mekanisme kerja yang jelas pada kondisi fisiologik dan patologik, namun pola produksi MMP oleh sel-sel tersebut dapat ditingkatkan oleh beberapa jenis sitokin yang ditemui pada jaringan periodontal yang terinflamsi, yaitu : IL-1, TNF- $\alpha$, cAMP, dan $\mathrm{PGE}_{2}$. Produk bakteri seperti enzim chymotrypsin juga dapat merangsang produksi MMP dari sel-sel tersebut. (Bartold \& Narayanan, 1998; Carranza et al, 2002).

Lipopolisakarida (LPS) jaringan dan TNF- $\alpha$ mengaktivasi MMP yang diproduksi oleh keratinosit. IL-1 meningkatkan jumlah MMP yang diproduksi oleh fibroblas sedangkan LPS merangsang $\mathrm{PGE}_{2}$ yang diproduksi oleh fibroblas. Aktivitas $\mathrm{PGE}_{2}$ menyebabkan penurunan proliferasi sel, penghambatan sintesis kolagen, dan dibantu dengan IL-6 dapat merangsang terjadinya resorpsi tulang. (Bartold \& Narayanan, 1998).

\section{Inhibitor MMP Sintetik}

Telah dikenal dua macam inhibitor MMP sintetik, yaitu peptidomimetic dan nonpeptidomimetic. Inhibitor peptidomimetic merupakan inhibitor 
Penggunaan Doksisiklin Hyclate Sebagai Inhibitor ...

MMP yang didesain menyerupai deret peptida substrat. Derivat hidroksamat merupakan inhibitor MMP yang tergolong dalam peptidomimetic, contohnya adalah Batimastat (BB-94) dan marimastat (BB-2516). Sedangkan yang termasuk golongan nonpeptidomimetic salah satunya adalah tetrasiklin. (Pirila, 2003).

Tetrasiklin mulai digunakan untuk pengobatan sejak tahun 1948. Tetrasiklin cukup efektif untuk digunakan melawan bakteri aerob dan anaerob, mikoplasma, klamidia, spirochaeta, beberapa protozoa, dan riketsia. Pada tahun1980, Golub dkk menemukan bahwa tetrasiklin memiliki kemampuan untuk menghambat aktivitas kolagenase dan dapat menurunkan aktivitas dan atau menurunkan jumlah MMP-1, MMP-2, MMP-3, MMP-8, MMP-9, MMP-13, dan MMP-20. (Pirila, 2003).

Tetrasiklin mampu menghambat MMP yang berasal dari berbagai macam sel, seperti : neutrofil, keratinosit, makrofag, osteoblas, kondrosit, fibroblast synovial, dan limfosit-T, serta mampu menghambat MMP yang berasal dari jaringan, seperti : kulit, gingiva, kornea, kartilago, dan synovial rheumatoid karena kemampuannya untuk mengkelat kation divalen yang diperlukan untuk aktivitas MMP sehingga MMP akan lebih peka terhadap proses degradasi proteolitik. Doksisiklin dan minosiklin merupakan golongan tetrasiklin yang lebih poten daripada golongan tetrasiklin yang lain. Untuk terapi periodontitis telah digunakan doksisiklin dengan dosis rendah yang dikemas dalam bentuk doksisiklin hyclate. (Pirila, 2003; Posthumus et al, 2004).

\section{Penggunaan Doksisiklin sebagai Inhibitor MMP pada Periodontitis}

Mekanisme kerja doksisiklin hyclate adalah dengan menekan aktivitas kolagenase, terutama yang dihasilkan oleh PMN leukosit. Walaupun obat ini berada pada golongan antibiotika, tetapi tidak menghasilkan efek antibakteri karena dosis sebanyak $20 \mathrm{mg}$ yang diberikan dua kali sehari terlalu rendah untuk mempengaruhi bakteri, oleh karena itu tidak akan muncul efek resistensi. Pemberian doksisiklin dosis rendah juga dapat mengurangi resorpsi tulang pada jaringan periodontal setempat selama pemberian obat. (Carranza et al, 2002; Gapski et al, 2004; Preshaw et al, 2004). Doksisiklin hyclate yang diberikan selama dua minggu mampu menghambat aktivitas kolagenase sebesar $60 \%-80 \%$ pada penderita periodontitis kronik. Pada penderita juga terjadi penurunan aktivitas kolagenase dalam cairan krevikular gingiva. Aktivitas kolagenase dihambat sekitar $70 \%$ oleh doksisiklin hyclate. (Weinberg, 2004)

Hasil studi klinik yang menggunakan doksisiklin hyclate sebagai terapi tambahan menunjukkan adanya penurunan kadar MMP-8 pada cairan krevikular gingiva. Selain itu telah dilakukan penelitian adanya efek klinik, biokimia, dan mikrobiologi dengan terapi menggunakan doksisiklin hyclate pada penyembuhan luka. Hasil penelitian menunjukkan adanya peningkatan penyembuhan luka setelah terapi bedah pada penderita periodontitis kronik dibandingkan dengan kelompok placebo disertai adanya pengurangan kedalaman 
poket pada poket dengan kedalaman $\geq 7 \mathrm{~mm}$. (Salvi \& Lang, 2005).

Penggunaan terapi tambahan dengan menggunakan doksisiklin dosis rendah juga efektif untuk penderita periodontitis dengan diabetes mellitus. Pada penderita diabetes tidak terkontrol disertai dengan periodontitis yang telah melanjut terjadi peningkatan aktivitas MMP-8 yang melebihi normal pada jaringan periodontal dan cairan krevikular gingiva. (SafkanSeppala B, 2001).

Perawatan scalling root planning (SRP) pada penderita periodontitis bertujuan untuk mengurangi jumlah bakteri dan produknya, sedangkan pemberian doksisiklin hyclate bertujuan untuk menghambat aktivitas MMP-8 yang diproduksi oleh sel-sel host sehingga dapat mencegah terjadinya kerusakan kolagen. Secara spesifik, doksisiklin hyclate menghambat kerusakan jaringan ikat dengan menghambat MMP yang telah aktif pada poket periodontal, atau dengan menghambat aktivasi kolagen yang inaktif, selain itu juga menghambat produksi dan aktivasi sitokin proinflamasi, seperti IL-1 dan TNF- $\alpha$ yang menstimulasi produksi kolagenase (Carranza et al, 2002; Weinberg, 2004)

Doksisiklin mampu menghambat aktivasi MMP dan aktivitasnya secara in vitro sehingga menyebabkan enzim tidak berfungsi karena adanya pengkelatan dari ion $\mathrm{Ca}^{2+}$ yang mencegah MMP dari aktivitas proteolitik. Penghambatan aktivitas MMP oleh doksisiklin dapat gagal bila konsentrasi $\mathrm{Ca}^{2+}$ tinggi. (Pirila, 2003).

Melalui SRP dan pemberian doksisiklin hyclate tersebut, aktivitas osteoklas dapat diturunkan sehingga kerusakan tulang dapat dikurangi. Selain itu pemberian doksisiklin hyclate dapat mencegah kerusakan kolagen sehingga kerusakan jaringan ikat juga dapat dikurangi. Kombinasi dari kedua perawatan ini menghasilkan adanya penurunan keparahan gejala klinik penyakit periodontitis. (Carranza et al, 2002).

\section{B. KESIMPULAN}

Pada periodontitis terjadi kerusakan kolagen pada ligamen periodontal karena adanya aktivitas MMP. Doksisiklin hyclate dapat menghambat aktivitas MMP dengan cara melakukan pengkelatan dengan ion $\mathrm{Ca}^{2+}$. Terapi tambahan dengan doksisiklin hyclate telah terbukti efektif untuk mencegah semakin bertambah parahnya kerusakan kolagen pada ligamen periodontal sehingga proses penyembuhan periodontitis dapat berjalan lebih cepat.

\section{UCAPAN TERIMAKASIH}

Penulis mengucapkan terima kasih kepada Lembaga penelitian dan pengembangan UIN maliki Malang yang telah mendanai penelitian ini.

\section{DAFTAR PUSTAKA}

Academy of General Dentistry. 2002. Periodontal Disease. Chicago. http://www.agd.org

American Academy of Periodontology. 2002.

Periodontal Disease. Chicago. http://www.perio.org

Anonim 1. Harian Terbit.Com

Anonim

http://www.sciencedirect.com/sci ence/article/pii/S0165572898002 410\&docid=rYUZ

U9JDq93MSM\&imgurl. Diakses tanggal 24 April 2012. 
Penggunaan Doksisiklin Hyclate Sebagai Inhibitor ...

Bartold PM \& Narayanan AS. 1998. Biology of The Periodontal Connective Tissues. USA, Quintessence Publishing co. Inc: pp.203-5, 211.

Berkovitz BKB, Moxham BJ, and Newman HM. 1995. The Periodontal Ligament in Health and Disease. 24 ${ }^{\text {th }}$. London, Mosby-Wolfe: pp.55-6, 71-2.

Carranza FA et al. 2002. Carranza's Clinical Periodontology. $\quad 9^{\text {th }}$ Edition. Philadelphia, WB. Saunders Company: pp. 140, 338, 398-400, 678-9, 681-2.

Deliemunthe, SH. 1995. Pengantar Priodonsia,

Perawatan

Periodontal, Periodonsia Klinis. Medan, Universitas Sumatra Utara Press: Hlm: 27,47.

Eley BM \& Cox DL. 1998. Bacterial Colonization of Saliva and Plaque. Clinical Infection Disease 4: pp.314-6.

Gapski R et al. 2004. Effect of Systemic Matrix Metalloproteinase Inhibiton on Periodontal Wound Repair: A Proof of Concept Trial. Journal Periodontology. 75(3): pp. 493.

Gendron R, Grenier D, Sorsa T, and Mayrand D. 1999. Inhibition of The Activities of Matrix Metalloproteinase 2, 8, and 9 by Chlorhexidine. Clinical and Diagnostic Laboratory Immunology. 6(3): pp.438.

Khoswanto C \& Ester A. 2004. Matrix Metalloproteinases in Oral Biology Research. Majalah Kedokteran Gigi. 37(4): hlm. 159.

Murphy G et al. 2002. Matrix Metalloproteinases in Arthritic Diseases. Arthritis Research Therapy. 4(3): pp. 3-4.
Nagase H, Suzuki K, Cawston TE, and Brew K. 1997. Involvement of A Region Nera Valine-69 of Tissue Inhibitor of Metalloproteinases (TIMP)-1 In The Interaction with Matrix Metalloproteinase-3

(Stromelysin-1). Biochemical Journal. 325: pp.163-4.

Perno M. 2001. Pharmacotherapy in Periodontal Therapy. Access: pp.9.

Pirila, E. 2003. Expression and Role Of Matrix Metalloproteinase and The Laminin-5 $\gamma 2$-Chain in Wound Healing and Cell Migration. Helsinki, University of Helsinky: pp.19, 28-30.

Posthumus MD, Limburg PC, Van Leeuwen MA, and Van Rijswijk MH. 2004. Matrix Metalloproteinase in Rheumatoid Arthritis. Desertasi. Groningen, University Hospital Groningen, Netherlands.

Preshaw PM et al. 2004. Subantimicrobial Dose Doxyxycycline As Adjunctive Treatment for Periodontitis. Journal Clinical Periodontology. 31:pp. 698-9, 704-5.

Salvi GE \& Lang NP. 2005. Host Response Modulation in The Management of Periodontal Disease. Journal Clinical Periodontology. 32(6). Pp. 118.

Seppala, BS. 2001. Periodontal Disease In Insulin-Dependent Diabetics. Desertasi. Helsinky, Faculty of Medicine of The University of Helsinky. Pp. 16.

Weinberg, MA. 2004. New Application of Doxyxycline Hyclate in Mendicine and Dentistry. US Pharmacist. 29(4). 